\title{
Antioxidant Properties and Effect of Abrus precatorius Leaves Extract on Haematological and Biochemical Parameters in Rats
}

\section{Fatima Mohammad Madaki*1(D), Adamu Yusuf Kabiru 1(D), Olofu Ogbadoyi Emmanuel 1(D), Abdullahi Mann 2}

1. Department of Biochemistry, Federal University of Technology, Minna, Nigeria

2. Department of Chemistry, Federal University of Technology, Minna, Nigeria.

\begin{tabular}{ll}
\hline Article Info & A B S T R A C T \\
\hline Article type: & Background \\
Original Article & Abrus precatorius (A. precatorius) is a herbal remedy commonly used in traditional \\
\hline Article History: & medicine. We investigated the phytochemical, antioxidant, toxic properties, and \\
Received: $2019-03-21$ & safety of $A$. precatorius leaves in rats.
\end{tabular}

Accepted: 2019-05-04

\section{Methods}

Phytochemical studies were conducted using standard procedures. The antioxidant

\section{Corresponding Author:}

Fatima M. Madaki;

Department of Biochemistry,

Federal University of Technology,

Minna, Nigeria.

E-mail:nmmadaki2@gmail.com properties were studied using the reducing power and 2, 2'- diphenyl-1picrylhydrazyl (DPPH) scavenging assays. The effect of the extract on biochemical and haematological parameters were evaluated after the oral administration of the extract at daily doses of 200,400 and $600 \mathrm{mg} / \mathrm{kg}$ of the rats' body weight for 28 days.

\section{Results}

Saponin was the most abundant $(202.25 \pm 9.25 \mathrm{mg} / 100 \mathrm{~g})$ while alkaloids $(9.69 \pm 0.34$ $\mathrm{mg} / 100 \mathrm{~g}$ ) were the least phytochemical content of $A$. precatorius. The extract had an $\mathrm{LD}_{50}$ value of $>5000 \mathrm{mg} / \mathrm{kg}$, demonstrating significant reducing power and DPPH scavenging activities (IC50 $=106.22 \mu \mathrm{g} / \mathrm{mL}$ ).

The extract significantly decreased the serum bilirubin and AST concentrations but increased the total proteins concentration compared with the controls $(\mathrm{p}<0.05)$. Urea, creatinine, ALP, ALT, chloride and albumin concentrations in the treated rats were not significantly different from those of the controls ( $p>0.05$ ). The $600 \mathrm{mg} / \mathrm{kg}$ dose significantly increased the $\mathrm{Hb}, \mathrm{PCV}, \mathrm{RBC}$ and $\mathrm{MCHC}$ of the treated rats, compared to those of the controls $(\mathrm{p}<0.05)$. All doses of the extract tested significantly increased the platelet count but did not alter the counts of MCV, MCH, TWBC, RDW, lymphocyte and neutrophils $(\mathrm{p}<0.05)$.

\section{Conclusions}

This study demonstrated that the A. precatorious leaves possess antioxidant and erythropoietic properties. It was also found to be relatively safe with regards to the liver and kidney integrity at concentrations up to $600 \mathrm{mg} / \mathrm{kg}$ body weight of the rats.

Keywords

Abrus precatorius; Antioxidant; Biochemical; Haematology; Phytochemicals.

How to Cite this Paper

Madaki FM, Kabiru AY, Emmanue 00, Mann A. Antioxidant Properties and Effect of Abrus precatorius Leaves Extract on Haematological and Biochemical Parameters in Rats. Iran J toxicol. 2019;(2):13-18

\section{INTRODUCTION}

Natural products are the free gifts of nature bestowed upon humanity with numerous therapeutic properties (1). Medicinal plants are rich sources of secondary metabolite with antioxidant properties that serve to prevent such diseases as cancer, diabetes, atherosclerosis, Alzheimer, diabetes, infections and more (2). According to the recent reports from the World Health Organisation (WHO), about $25 \%$ of current drugs are plant-based and more than $75 \%$ of the world's population rely on medicinal plants for primary health care needs (므). Also, WHO has recommended application of herbal medicine, especially in areas with limited access to modern healthcare services. However, WHO emphasizes that the safety of all herbal medicine should be the overriding criterion in their selection and usage.

The plant, A. precatorius (Fabacea family) is locally known as "Idon Zakara" in Hausa dialect of Nigeria. It 
grows widely in tropical areas, such as southern India and Africa. In Nigeria, A. precatorius leaves have been used for the treatment of numerous diseases, including malaria, typhoid, hepatitis and respiratory tract infections ( $\underline{4})$. The leaves have also been reported for their cytotoxicity, anti-diabetic and antimicrobial activities (ㅁ). The root and leaves are used in traditional medicine to treat cancer (ㅁ), chronic nephritis (ㅁ), bronchitis, fever, asthma, stomatitis, and diabetes (므). The stem, root and leaves of this plant are also used to treat snake bites, tuberculosis, protozoal infections and insecticide poisoning $(\underline{9}, \underline{10})$. The seeds have been reported for the toxic effect on kidneys, liver, heart, spleen, intestine and lungs (4). However, the leaves have been known to contain low concentrations of a deadly poison known as "abrin" $(\underline{11,12})$. The aim of the present study was to evaluate the phytochemical, antioxidant, toxic properties, and the safety profile of $A$. precatorius leaves in rats.

\section{MATERIALS AND METHODS}

Sample Collection and Preparation: Fresh leaves of $A$. precatorius were collected from Minna Niger State in Nigeria and were identified by an expert botanist at the Department of Biological Science, Federal University of Technology, Minna, Nigeria (FUTMINNA).

Experimental Animals: Healthy albino rats were procured from the animal holding unit at FUTMINNA. They were allowed unrestricted access to rat pellet food and water.

Ethical Approval: The ethical principles governing the use of laboratory animals as set by the Federal University of Technology, Minna; Committee on Ethics for Medical and Scientific Research. Also, the existing internationally accepted principles of laboratory animal use and care as contained in the Canadian Council on Animal Care Guidelines and Protocol Review were duly observed.

Reagent and Chemicals: Ascorbic acid was obtained from Merck Co. (Darmstadt, Germany) and 1,1diphenyl-2-picrylhydrazyl radical (DPPH) from SigmaAldrich Co. (St. Louis, USA). All biochemical assay kits were obtained from either Randox Laboratories (Ardmore, UK) or Agappe Diagnostics (Kerala, India). All other chemicals used in this study were of analytical grades and obtained locally.

Sample Preparation and Extraction: The collected leaves were washed and dried out for 2 weeks at $37^{\circ} \mathrm{C}$ and powdered, using a grinding mill. A 50g-sample of the material was extracted with $200 \mathrm{ml}$ of methanol, using soxhlet apparatus (Fujian, China) and the resulting extract was concentrated, using a water bath at low temperature.

\section{Phytochemical Analysis: Quantitative} phytochemical analysis of the crude extract of $A$. precatorius was carried out, using standard procedures as described previously $(\underline{13,14})$.

Antioxidant Study: The antioxidant activity of the extracts was measured at varying concentrations (20$100 \mu \mathrm{g} / \mathrm{ml}$ ), using ascorbic acid as the reference and
DPPH assay $(\underline{15})$. The reducing power of the extract was determined by a previously described method (16).

Toxicological Study: The acute toxicity of the extract was evaluated as described by Lorke's (17). The subacute toxicity was determined based on the method described by Yusuf et al. (18).

Animals \& Grouping: Twenty albino rats were randomly divided into 4 groups of 5 rats each. Group 1 rats were given normal saline orally $(10 \mathrm{ml} / \mathrm{kg})$ and served as the controls. Groups 2, 3 and 4 received 200, 400 and $600 \mathrm{mg} / \mathrm{kg}$ the methanol extract of $A$. precatorius, respectively, for 28 days. Blood samples were collected and centrifuged to separate the sera for biochemical analyses as described previously (19).

Biochemical Parameters: The serum levels of AST, ALT, ALP, total proteins, albumin, bilirubin, urea, creatinine and chloride were determined spectrophotometrically, using standard methods (2024).

Haematological Parameters: The hematological constituents, such as haemoglobin ( $\mathrm{Hb})$, packed cell volume (PCV), red blood cells (RBC), mean corpuscular volume (MCV), mean corpuscular haemoglobin (MCH) and the concentration (MCHC), white blood cells (WBC), platelet count (PLT) and differential counts: granulocytes, lymphocytes, eosinophils, monocytes and neutrophils were determined, using an automated haematologic analyzer (SYSMEX KX21, Japan), employing the methods described by Dacie and Lewis (25).

Data Analysis: The data were analyzed using statistical package for social science (SPSS, v18). The differences among the groups were compared using analysis of variance (ANOVA) followed by Duncan's multiple range test at $\mathrm{P}<0.05$ confidence level.

\section{RESULTS}

Phytochemical \& Acute Toxicity Study: The quantitative analysis revealed saponin to be the most abundant phytochemical component (202.25 \pm 9.25 $\mathrm{mg} / 100 \mathrm{~g})$, followed by tannins (129.12 \pm 9.30 $\mathrm{mg} / 100 \mathrm{~g}$ ) while alkaloids were the least abundant phytochemical content $(9.69 \pm 0.34 \mathrm{mg} / 100 \mathrm{~g})$ of the $A$. precatorius extract (Table 1 ). The acute toxicity study did not cause mortality, with the $\mathrm{LD}_{50}$ concentration being greater than $5000 \mathrm{mg} / \mathrm{kg}$ in the rats (Table 2).

Table 1. Quantitative phytochemical contents of $A$. precatorius

\begin{tabular}{lc} 
& extract. \\
\hline Phytochemical & Concentration $(\mathrm{mg} / 100 \mathrm{~g})$ \\
\hline Flavonoids & $60.97 \pm 3.20$ \\
Phenols & $121.95 \pm 11.36$ \\
Tannins & $129.12 \pm 9.30$ \\
Saponins & $202.25 \pm 9.25$ \\
Alkaloids & $9.69 \pm 0.34$ \\
\hline
\end{tabular}

Table 2. Acute toxicity profile of $A$. precatorius extract.

\begin{tabular}{cccc}
\hline Group & Dose $(\mathrm{mg} / \mathrm{kg})$ & No of animals & Mortality \\
\hline Group 1 & 10 & 3 & $0 / 3$ \\
Group 2 & 100 & 3 & $0 / 3$ \\
Group 3 & 1000 & 3 & $0 / 3$ \\
Group 4 & 1600 & 3 & $0 / 3$ \\
Group 5 & 2900 & 3 & $0 / 3$ \\
Group 6 & 5000 & 3 & $0 / 3$ \\
\hline
\end{tabular}


In-vitro Antioxidant Activities: The extract of $A$. precatorius inhibited DPPH radicals with an $\mathrm{IC}_{50}$ value of $106.22 \mu \mathrm{g} / \mathrm{ml}$ while ascorbic acid had an $\mathrm{IC}_{50}$ value of $33.970 \mu \mathrm{g} / \mathrm{ml}$ (Figure 1). The reducing power analysis of the extract also showed some antioxidant activity, resulting in an increase in absorbance with the increasing concentrations of the extract (Figure 2).

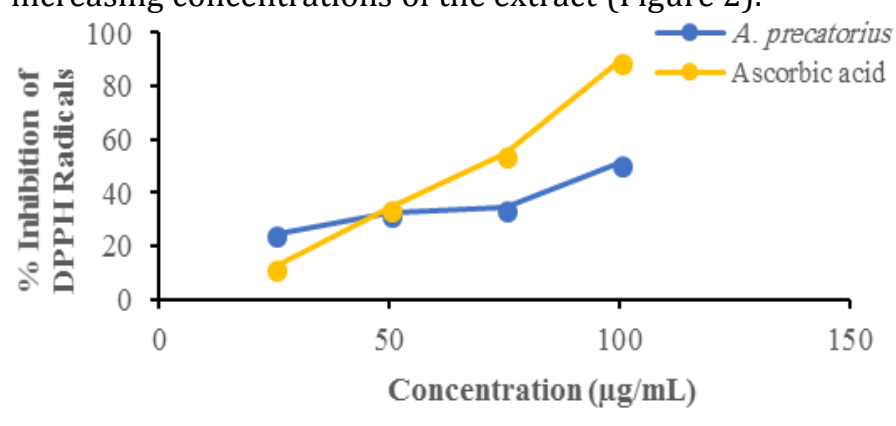

Figure 1. DPPH Radical Scavenging Activity of A. precatorius extract.

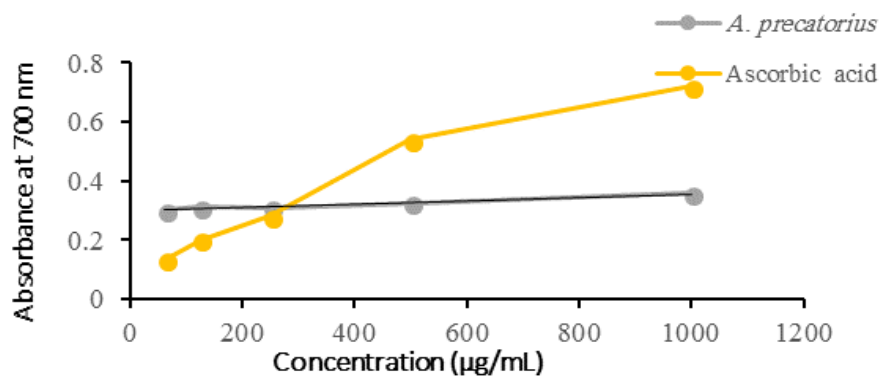

Figure 2. The reducing activity of $A$. precatorius extract.
Biochemical Parameters: The extract of A. precatorius at 200,400 and $600 \mathrm{mg} / \mathrm{kg}$ concentrations increased total serum proteins from $97.85 \pm 3.50 \mathrm{mg} / \mathrm{dl}$ (controls) to $119.70 \pm 0.00,125.40 \pm 32.30$ and $113.05 \pm 25.65 \mathrm{mg} / \mathrm{dl}$, respectively (Table 3 ). At the same concentrations, the extract decreased the bilirubin concentrations from $0.70 \pm 0.01 \mathrm{mg} / \mathrm{dl}$ (controls) to $0.64 \pm 0.03, \quad 0.38 \pm 0.00$ and $0.25 \pm 0.00$ $\mathrm{mg} / \mathrm{dl}$, respectively. Similarly, the AST activities declined from $77.40 \pm 1.80 \mathrm{U} / \mathrm{l}$ (controls) to $45.00 \pm 1.80$, $37.80 \pm 9.00$, and $43.21 \pm 10.81 \mathrm{U} / \mathrm{l}$ in rats treated with 200,400 and $600 \mathrm{mg} / \mathrm{kg}$ of the extract, respectively. At the same extract concentrations, urea, creatinine(Table 4), ALP, ALT, chloride and albumin concentrations were not significantly different in experimental rats from those in the control group.

Hematological Parameters: At a dose of 600 $\mathrm{mg} / \mathrm{kg}$, the extract significantly increased the haemoglobin, packed cell volume, red blood cells and MCHC of the treated rats compared with those of the controls. All doses of the extract tested significantly increased the platelet count $(\mathrm{p}<0.05)$ compared to that of the controls. However, MCV, MCH, TWBC, red blood cells distribution width (RDW), lymphocyte and neutrophil counts were not significantly different among rats treated with any concentrations of the extract compared to those for the controls (Table 5).

Table 3. Effect of A. precatorius extract on liver function.

\begin{tabular}{lllcccc}
\hline \multicolumn{1}{c}{ Group } & \multicolumn{1}{c}{ Total Proteins } & Bilirubin & ALP & Albumin & AST & ALT \\
\hline Control & $97.85 \pm 3.50^{\mathrm{a}}$ & $0.70 \pm 0.01^{\mathrm{d}}$ & $96.25 \pm 3.75^{\mathrm{a}}$ & $5.69 \pm 0.06^{\mathrm{a}}$ & $77.40 \pm 1.80^{\mathrm{b}}$ & $57.35 \pm 3.67$ a \\
$200 \mathrm{mg} / \mathrm{kg}$ & $119.70 \pm 0.00^{\mathrm{b}}$ & $0.64 \pm 0.03^{\mathrm{c}}$ & $94.22 \pm 4.66^{\mathrm{a}}$ & $4.46 \pm 0.71^{\mathrm{a}}$ & $45.00 \pm 1.80^{\mathrm{a}}$ & $55.68 \pm 3.677^{\mathrm{a}}$ \\
$400 \mathrm{mg} / \mathrm{kg}$ & $125.40 \pm 32.30^{\mathrm{b}}$ & $0.38 \pm 0.00^{\mathrm{b}}$ & $91.28 \pm 3.74^{\mathrm{a}}$ & $5.63 \pm 0.52^{\mathrm{a}}$ & $37.80 \pm 9.00^{\mathrm{a}}$ & $61.90 \pm 4.32^{\mathrm{a}}$ \\
$600 \mathrm{mg} / \mathrm{kg}$ & $113.05 \pm 25.65^{\mathrm{b}}$ & $0.25 \pm 0.00^{\mathrm{a}}$ & $96.25 \pm 3,75^{\mathrm{a}}$ & $5.63 \pm 0.29 \mathrm{a}$ & $43.21 \pm 10.81^{\mathrm{a}}$ & $58.35 \pm 4.35$ a \\
\hline
\end{tabular}

Values are mean \pm SEM of 3 determinations. The values along the same row with different superscripts were significantly different

$(p<0.05)$. The superscript alphabet "d" indicates the highest significance level followed by "c" and "b", while "a" indicates the least significance level at $\mathrm{p}<0.05$.

Table 4. Effect of A. precatorius extract on urea, creatinine and electrolytes.

\begin{tabular}{llll}
\hline \multicolumn{1}{c}{ Group } & \multicolumn{1}{c}{ Urea } & \multicolumn{1}{c}{ Creatinine } & \multicolumn{1}{c}{ Chloride } \\
\hline Control & $19.72 \pm 1.69^{\mathrm{a}}$ & $2.51 \pm 0.50^{\mathrm{a}}$ & $190.00 \pm 0.00^{\mathrm{a}}$ \\
$200 \mathrm{mg} / \mathrm{kg}$ & $17.00 \pm 3.28 \mathrm{a}$ & $2.00 \pm 1.01^{\mathrm{a}}$ & $149.99 \pm 8.57^{\mathrm{a}}$ \\
$400 \mathrm{mg} / \mathrm{kg}$ & $25.92 \pm 0.00^{\mathrm{a}}$ & $1.99 \pm 0.00^{\mathrm{a}}$ & $156.42 \pm 2.14^{\mathrm{a}}$ \\
$600 \mathrm{mg} / \mathrm{kg}$ & $20.56 \pm 2.53^{\mathrm{a}}$ & $1.99 \pm 1.00^{\mathrm{a}}$ & $163.68 \pm 26.544^{\mathrm{a}}$ \\
\hline
\end{tabular}

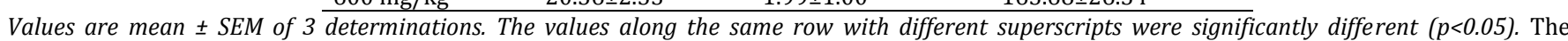
superscript alphabet "d" indicates the highest significance level followed by "c" and "b", while "a" indicates the least significance level at $p<0.05$.

Table 5. Effect of A. precatorius extract on hematological parameters.

\begin{tabular}{|c|c|c|c|c|}
\hline Component & Controls & $200 \mathrm{mg} / \mathrm{kg}$ & $400 \mathrm{mg} / \mathrm{kg}$ & $600 \mathrm{mg} / \mathrm{kg}$ \\
\hline $\mathrm{Hb}$ & $14.56 \pm 0.78^{\mathrm{a}}$ & $15.43 \pm 0.24^{\mathrm{a}}$ & $14.53 \pm 1.90^{a}$ & $16.35 \pm 1.67 \mathrm{~b}$ \\
\hline PCV & $42.34 \pm 0.45^{\text {a }}$ & $43.45 \pm 1.82^{a}$ & $44.32 \pm 1.98 \mathrm{a}$ & $49.75 \pm 1.32 \mathrm{~b}$ \\
\hline MCV & $45.42 \pm 2.67$ a & $46.43 \pm 2.56^{a}$ & $45.42 \pm 2.67$ a & $43.45 \pm 2.34$ a \\
\hline MCH & $14.32 \pm 0.56^{a}$ & $15.45 \pm 0.78^{a}$ & $15.21 \pm 0.89 \mathrm{a}$ & $16.56 \pm 0.88^{a}$ \\
\hline MCHC & $40.89 \pm 1.99^{a}$ & $48.32 . \pm 2.34 \mathrm{a}, \mathrm{b}$ & $42.89 \pm 0.89 \mathrm{a}$ & $52.34 \pm 1.90^{\mathrm{b}}$ \\
\hline RBC & $8.03 \pm 0.23$ a & $8.17 \pm 0.79$ a & $8.91 \pm 0.67 \mathrm{a}, \mathrm{b}$ & $9.4 .62 \pm 0.46^{b}$ \\
\hline PLC & $198.23 \pm 4.56^{a}$ & $219.67 \pm 3.78^{b}$ & $235.56 \pm 3.45 \mathrm{~b}$ & $226.76 \pm 4.56^{b}$ \\
\hline TWBC & $5.91 \pm 0.46^{\mathrm{a}}$ & $5.32 \pm 0.46^{\mathrm{a}}$ & $5.06 \pm 0.45 \mathrm{a}$ & $5.39 \pm 0.29 \mathrm{a}$ \\
\hline Neutrophils & $33.57 \pm 0.68^{a}$ & $33.46 \pm 0.56^{a}$ & $30.67 \pm 0.56^{a}$ & $31.24 \pm 0.98^{a}$ \\
\hline Lymphocyte & $43.46 \pm 0.89 a$ & $45.435 \pm 0.79 a$ & $42.35 \pm 1.35 \mathrm{a}$ & $41.57 \pm 1.68$ a \\
\hline RDW+ & $34.56 \pm 0.45$ a & $33.56 \pm 0.57 \mathrm{a}$ & $35.67 \pm 0.45$ a & $33.56 \pm 0.7$ a \\
\hline
\end{tabular}

Values are mean \pm SEM of 3 determinations. The values along the same row with different superscripts were significantly different ( $p<0.05)$. The superscript alphabet "d" indicates the highest significance level followed by "c $c$ " and "b", while "a" indicates the least significance level at $p<0.05$. 


\section{DISCUSSION}

The significant amount of secondary metabolites, including flavonoids, alkaloids and saponins in $A$. precatorius leaves is an indication that they contain phytochemicals that could confer considerable health benefits to individuals who consume the plant appropriately. Flavonoids occur in foods either as free monomers (quercetin, catechin) or oligomers (procyanidins), bound to saccharides as glycosides. The significant amount of phytochemicals in the extact, as reported in this study, is in close agreement with the amounts reported by Ikechukwu et al. (26) for the contents of saponins (8.22\% w/v), alkaloids $(6.00 \%$ $\mathrm{w} / \mathrm{v})$ and flavonoids $(30.05 \% \mathrm{w} / \mathrm{v})$ in $A$. precatorius leaves (Table 1).

The consumption of flavonoid-rich foods is associated with low incidence of coronary heart disease, myocardial infarction, cancer, neurodegenerative

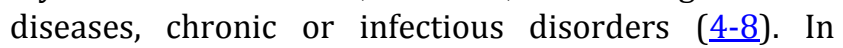
addition to their antioxidant properties, flavonoids, alkaloids and saponins have been reported to exhibit multiple biological benefits against viral, bacterial, inflammatory, vasodilatory, cancer and ischemic conditions (27). In the pathogenicity of these diseases, oxidative stress has been assumed to play a major role, suggesting that flavonoids exert their health benefits through antioxidant mechanism (2). The activities of the extract against DPPH radicals could, therefore, be attributed to the presence of these phytochemicals.

The dose-dependent increase in the antioxidant activities of $A$. Precatorious, as observed in this study, is in line with that reported by another study (28). This indicates that the antioxidant potentials of Newbouldia laevis and Crateva adansonii extracts increase as the concentrations rise. The $\mathrm{IC}_{50}$ values of $A$. precaterious was also far better than the scavenging activities reported for some other medicinal plants, such as Padina pavonica ( $\mathrm{IC}_{50}=5.59 \mathrm{mg} / \mathrm{ml}$ ), Laurenica majuscule ( $\left.\mathrm{IC}_{50}=14.3 \mathrm{mg} / \mathrm{ml}\right)$, and Laurencia catarinensis $\left(\mathrm{IC}_{50}=53.8 \mathrm{mg} / \mathrm{ml}\right)$ (29). The high antioxidant activities could be translated to higher medicinal value of the plant extract. The high flavonoid contents of $A$. precatorius leaves may have contributed significantly to the findings in this study, which were in

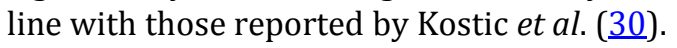

The estimated $\mathrm{LD}_{50}$ of the extracts being greater than $5000 \mathrm{mg} / \mathrm{kg}$ suggests that the extract is fairly safe with a very low toxicity. This finding is in agreement with a previous study (26), reporting that the extract of $A$. precatorius leaves are safe for consumption as no signs of toxicity or death was ever recorded even at a concentration of $500 \mathrm{mg} / \mathrm{kg}$ of the extract (26). This is contrary to the findings of Tion et al. (1) who reported that the estimated $\mathrm{LD}_{50}$ of the $A$. precatorius seed extracts to be at doses of $175-187.5 \mathrm{mg} / \mathrm{kg}$. This finding also contradicts the report of Saganuwan et al. (푸) who indicated that the $\mathrm{LD}_{50}$ of the aqueous extract in mice was $2558.9 \mathrm{mg} / \mathrm{kg}$.
The toxicity of natural products particularly plant extracts has been implicated in the alterations of biochemical parameters (르). Transaminases are liver enzymes at low concentrations in the serum. The marked decreases of aspartate aminotransferase concentration may not necessarily indicate a compromised liver function in the appropriate clinical context ( $\underline{33})$. This is because it has been established that AST activities are elevated when there is injury to the liver or other organs such as heart, muscle, brain and kidneys ( $\underline{33})$. However, aminotransferases play a major role in amino acid metabolism through intracellular biochemical regulations (19). The marked decrease in AST could; however, affect amino acid metabolism and consequently impact ATP generation in animals. However, the preserved activities of aspartate transaminase, alkaline phosphatase and serum albumin concentration suggest that the functional integrity of liver had not been compromised by the administration of $A$. precatorius extract in rats.

The concentrations of total serum proteins, albumin, bilirubin, urea, creatinine and electrolytes are useful markers of secretory, synthetic and excretory functions of the liver and kidneys ( $\underline{34}$ ). The observed increases in the total serum proteins and a decrease in bilirubin suggest a compromised synthetic ability of the liver due to the administration of the extract. The extract might have increased the functional activity of the liver by interfering with the equilibrium in the synthesis and degradation, removal or clearance of total proteins and bilirubin in the animals. A similar finding has previously been reported in rats that were given snail haemolymph (34). The increase in the total serum proteins could; however, lead to dehydration which is detrimental to cellular homeostasis. This will negatively affect the metabolic activities of the liver and consequently the health of the animals. Urea and creatinine are known to accumulate in the urine, when the normal glomerular function is compromised. Therefore, the preserved concentration of urea and creatinine in rats treated with $A$. Precatorious extract reflects a preserved glomerular function (19).

The erythrocyte parameters including RBC, PCV, $\mathrm{Hb}$, $\mathrm{MCH}, \mathrm{MCHC}$, and RDW are useful indicators of the levels of circulatory erythrocytes and serve as useful indices of the bone marrow capacity to produce RBC in response to the administration of drugs, toxins or plant extracts $(\underline{35})$. The significant increase in haemoglobin, packed cell volume, red blood cells and MCHC following treatment with $600 \mathrm{mg} / \mathrm{kg}$ of $A$. Precatorious is an indication that erythropoiesis can be stimulated by the extract. The extract must have increased the rate of erythropoietin synthesis and its release in the kidneys, which is the humoral regulator of RBC production ( $\underline{32})$. Therefore, the extract could be used in the management of anaemia. Similar observation has been made in rats treated with the extract of $T$. occidentalis $(\underline{35})$. The observation with the white blood cell and lymphocyte counts indicated that the extract exerted leucopoetic and possibly immunomodulatory effects on the treated animals ( $\underline{34}$ ). 


\section{CONCLUSIONS}

The findings demonstrated that the methanol extract of A. precatorious has antioxidant and erythropoietic properties. The extract was also found to be relatively safe at concentrations of up to $600 \mathrm{mg} / \mathrm{kg}$ in rats with respect to the function and integrity of the liver and kidneys after four weeks of daily administration.

\section{ACKNOWLEDGEMENT}

The authors would like to appreciate the technical laboratory staff, Department of Biochemistry, Federal University of Technology Minna for their kind assistance and support toward this study.

\section{CONFLICT OF INTEREST}

The authors declared no conflict of interests in conducting this study with any internal or external entity.

\section{REFERENCES}

1. Tion MT, Fotina H, Saganuwan SA. Phytochemical screening, proximate analysis, median lethal dose (LD50), hematological and biochemical effects of various extracts of Abrus precatorius seeds in Mus musculus. Journal of Advanced Veterinary and Animal Research. 2018;5(3):354-360.

2. Lawal B, Shittu OK, Inje OF, Berinyuy EB, Muhammed H. Potential Antioxidants and Hepatoprotectives from African Natural Products: A Review. Clinical Phytoscience. 2017;2(23):1-66.

3. WHO. Legal Status of traditional medicine and complementary/alternative medicine: A worldwide review. WHO Publishing 1; 2001.

4. Saganuwan SA, Onyeyili PA. Biochemical effects of aqueous leaf extract of Abrus precatorius (Jecquirity bean) in Swiss albino mice. Herba Polonica. 2010;56(3):63-80.

5. Alayande KA, Sabiu S, Ashafa OTA. Medicinal properties of Abrus precatorius Linn. leaf extract: antimicrobial, cytotoxicity and carbohydrate metabolising enzymes' inhibitory potential. Transactions of the Royal Society of South Africa. 2017;72(3):242-250.

6. Sivakumar R, Alagesaboopathi C. Studies on cytotoxicity and antitumor screening of red and white forms of $A b r u s$ precatorius. African Journal of Biotechnology. 2008;7(22):3984-3988.

7. Ligha A, Jaja B, Numbere N. Protective effect of Abrus precatorius seed extract following alcohol induced renal damage. European Journal of Scientific Research. 2009;25(3):428-436.

8. Saganuwan AS. Phytochemical and pharmaceutical potentials. Abstract Book, the first Mediterranean Symposium of Medicinal and Aromatic Plants. Held on April 17-20, 2013, Gazimauosa, Turkish Republic of Northern Cyprus. 2013; p. 366.

9. Sunday OJ, Babatunde SK, Ajiboye, AE, Adedayo RM, Ajao MA, Ajuwon BI. Evaluation of phytochemical properties and in-vitro antibacterial activity of the aqueous extracts of leaf, seed and root of Abrus precatorius Linn. against
Salmonella and Shigella. Asian Pacific Journal of Tropical Biomedicine. 2016;6(9):755-759.

10. Attal AR, Otari KV, Shete RV, Upasani CD, Nandgude TD. Abrus precatorius Linnaeus: a phytopharmacological review. Journal of Pharmacy Research. 2010;3(11):2585-2587.

11. Adedapo AA, Omoloye OA, Ohore OG. Studies on the toxicity of an aqueous extract of the leaves of $A b r u s$ precatoriusin rats. Onderstepport Journal of Veterinary Research. 2007;74:31-36.

12. Reedman L, Shih RD. Hung O. Survival after an intentional ingestion of crushed Abrus seeds. Western Journal of Emergency Medicine. 2008;9:157-159.

13. Trease GE. Evans WC. Textbook of Pharmacognosy. 12th Ed., Bailliere Tindall, London. 1983.

14. Harborne JB. Phytochemical Methods: A Guide to Modern Technique of Plant Analysis. 3rd Ed., Springer, London, ISBN: 9780412572708, 1998; pp: 88-185.

15. Blois MS. Antioxidant determinations by the use of a stable free radical. Nature. 1958;181:1199-1200.

16. Oyaizu M. Studies on products of browning reactionantioxidative activities of products of browning reaction prepared from glucosamine. Japan Journal of Nutrition. 1986; 44:307-315.

17. Lorke D. A new approach to practical acute toxicity testing. Archive of Toxicology. 1983;54:275-287.

18. Yusuf AA, Lawal B, Yusuf MA, Omonije YO, Adejoke AA, Raji FH, Wenawo DL. Free Radical Scavenging, Antimicrobial Activities and Effect of Sub-Acute Exposure to Nigerian Xylopia Aethiopica Seed Extract On Liver and Kidney Functional Indices of Albino Rats. Iranian Journal of Toxicology. 2018;12(3):51-58.

19. Lawal B, Shittu OK. Oibiokpa IF, Mohammed H, Umar, SI, Haruna GM. Antimicrobial evaluation, acute and subacute toxicity studies of Allium sativum. Journal of Acute Disease. 2016;5(4):296-301.

20. Tietz NW. Clinical guide to laboratory tests. 3rd ed. Philadelphia, PA: WB Saunders Company; 1995, p. 286288.

21. Reitman S, Frankel S. A colorimetric method for the determination of serum glutamic oxalacetic and glutamic pyruvic transaminases. American Journal of Clinical Pathology. 1957;28:56-63.

22. Gornall AC, Bardawill CJ, David MM. Determination of serum protein by means of biuret reaction. Journal of Biology and Chemistry. 1949;177:751-766.

23. Doumas BT, Watson WA, Biggs HG. Albumin standards and the measurement of serum albumin with bromocresol green. Clinical Chemistry Acta. 1971;31:8796.

24. Blass KG, Thierbert RJ, Lam LK. A study of the mechanism of the Jaff'e reaction. Z Klin Chem Klin Biochem. 1974;12:336-343.

25. Dacie, JV, Lewis SM. Practical Haematology. 11th Ed., Elsevier, London, UK. 2002; pp:380-382.

26. Ikechukwu UR, Sangodare RSA, Muhammad KH, Lilian, AC. Effect of Methanol Extract of Abrus precatorius Leaves on Male Wistar Albino Rats Induced Liver Damage using Carbon Tetrachloride $\left(\mathrm{CCl}_{4}\right)$. Journal of Biological Sciences. 2015;15:116-123. 
27. Prochazkova D, Bousova I, Wilhelmova N. Antioxidant and prooxidant properties of flavonoids. Fitoterapia. 2011:82:513-523.

28. Tsado NA, Lawal B, Ossa PC, Jagaba A, Kontagora GN, Gboke JA, Umar AM, Oladunjoye JO. Antioxidants and Antimicrobial Activities of Methanol Extract of Newbouldia laevis and Crateva adansonii. Journal of Pharmacy and Allied Health Sciences. 2016. DOI:10.3923/jpahs.2016.

29. Al-Enazi NM, Awaad AS, Zain ME, Alqasoumi SI. Antimicrobial, antioxidant and anticancer activities of Laurenciacata rinensis, Laurenciama juscula and Padina pavonica extracts. Saudi Pharmaceutical Journal. 2018;26:44-52.

30. Kostic DA, DS, Dimitrijevic SS, Mitic MN, Mitic GS, Stojanovic S, Zivanovic AV. Phenolic content and antioxidant activities of fruit extracts of Morusnigra L (Moraceae) from Southeast Serbia. Tropical J Pharmaceutical Research. 2013;12:105-110.

31. Saganuwan SA, Onyeyili PA. The Paradox of Human Equivalent Dose Formula: A Canonical case study of
Abrus precatorius aqueous leaf extract in monogastric animals. Macedonian Veterinary Review. 2016;39(1):2332.

32. Shittu OK, Lawal B, Blessing Uchenna AB, Haruna GM, Abubakar AN, Berinyuy EB. Alteration in Biochemical Indices Following Chronic Administration of Methanolic Extract of Nigeria Bee Propolis in Wistar Rats. Asian Pacific Journal of Tropical Disease. 2015;5(8):654-657.

33. Teschke R. Hepatotoxicity by drugs and dietary supplements: Safety perspectives on clinical and regulatory issues. Annals of Hepatology. 2009;8:184-195.

34. Bashir L, Shittu OK, Busari MB, Sani S. Aisha MI. Safety evaluation of giant African land snails (Archachatina maginata) haemolymph on haematological and biochemical parameters of albino rats. Journal of Advance Medical and Pharmaceutical Sciences. 2015;3(3):122-130.

35. Lawal B, Shittu OK, Rotimi, AA, Olalekan, AA, Kamooru AA, Ossai PC. Effect of Methanol Extract of Telfairia occcidentalis on Haematological Parameters in Wistar Rats. Journal of Medical Sciences. 2015;15(5):246-250. 